\title{
O projeto do novo Código de Processo Civil e o direito fundamental à celeridade processual
}

\section{The project of the New Code of Civil Procedure and the fundamental right of process celerity}

\author{
Margareth Vetis Zaganelli* \\ Gizelly Gussye Amaral Rabello**
}

\section{Resumo}

O presente artigo aborda a consagração da celeridade processual como um direito fundamental enunciado na Constituição Federal brasileira de 1988 e a tentativa de sua consolidação na legislação infraconstitucional. Faz uma reflexão acerca do tempo no processo, ressaltando a sua essencialidade para a observância de outros valores fundamentais, como o devido processo legal, a ampla defesa e a segurança jurídica, bem como a sua face mais perigosa - a da morosidade -, a partir da análise na doutrina pertinente e no Direito Comparado. A seguir, trata da consagração do princípio da razoável duração do processo em sede constitucional e da necessidade de observância dos mandamentos voltados à ágil solução das controvérsias como um fator de efetivação da tutela jurídica de direitos. Por derradeiro, examina os ideais voltados à concretização do processo justo e a enunciação da celeridade processual no capítulo I do projeto de novo Código de Processo Civil brasileiro.

Palavras-chave: Celeridade. Processo civil. Razoável duração do processo.

Doutora em Direito pela Universidade Federal de Minas Gerais (UFMG). Mestre em Educação pela Universidade Federal do Espírito Santo (UFES). Professora Associada do Departamento de Direito e do Curso de Mestrado em Direito Processual Civil da Universidade Federal do Espírito Santo (UFES). Vice-Diretora do Centro de Ciências Jurídicas e Econômicas da Universidade Federal do Espírito Santo (UFES). Coordenadora do Grupo de Pesquisa em Direito Probatório do Programa de Mestrado em Direito Processual Civil da Universidade Federal do Espírito Santo (UFES). Vitória - Espírito Santo - Brasil. Email: mvetis@terra.com.br.

* Mestranda em Direito Processual Civil pela Universidade Federal do Espírito Santo (UFES). Especialista em Direito Público pela Faculdade São Geraldo. Advogada. Vitória - Espírito Santo - Brasil. Email: gellygussye@yahoo.com.br 


\section{Abstract}

This article deals with the consecration of the procedural haste as a fundamental right contained in the Brazilian Federal Constitution of 1988, and the attempt to consolidate its position in infraconstitutional legislation. A reflection is made on the consequences of the passage of time in court procedures, underscoring their essentiality to the observance of other fundamental values such as the due process, the right of defense and legal certainty, as well as its most dangerous, slow, from the analysis in the relevant doctrine and comparative law. Further, this essay analyses the consecration of the principle of reasonable duration of process in the Constitution, and the need for observance of the commandments related to agile solution of controversies as a factor of effective legal protection of rights. Last, the ideas focused on the implementation of fair trial and the enunciation of the procedural haste are examined, as foreseen in chapter I of the new code of Brazilian Civil procedure.

Keywords: Celerity. Civil procedure. Reasonable duration of process.

\section{Introdução}

O tema "celeridade processual", indissociável de questões como a instrumentalidade do processo, os efeitos do tempo sobre a prestação do serviço jurisdicional e os direitos e garantias processuais, apesar de amplamente discutido na doutrina e na jurisprudência pátria, ainda é alvo de críticas e merece a nossa atenção, na busca por mecanismos efetivos e seguros, capazes de garantir uma prestação jurisdicional de resultado justo.

Não raras são as afirmações de que o tempo é o vilão do processo; de que é preciso alterar e simplificar procedimentos; suprimir recursos; impedir o abarrotamento dos tribunais; incentivar a utilização de métodos alternativos de solução de controvérsias; e, unanimemente, que o Judiciário brasileiro está engessado, é moroso e exageradamente burocrático. Diante dessa situação, o legislador reformador e infraconstitucional vem, sistematicamente, tanto alterando o texto constitucional quanto criando um sem número de novas leis, no 
afã de conferir maior rapidez e eficiência ao procedimento jurisdicional e, com isso, maiores garantias de efetivo acesso ao direito substancial.

No período compreendido entre a segunda metade do século XIX e o início do século $X X$, a doutrina jurídica se empenhou na tentativa de consolidar o Direito Processual como um ramo autônomo da ciência jurídica, desvinculando-o do direito material. Entretanto, o que se verificou foi um verdadeiro soterramento do papel instrumental do processo na atuação do direito substancial. Com a autonomia do Direito Processual, fundada principalmente na teorização do direito de ação e da relação jurídica processual, desenvolveu-se uma visão altamente tecnicista de um processo como um fim em si mesmo, desvinculado da obrigação de observar as necessidades próprias do direito material.

A situação começou a alterar-se ainda no século $X X$, quando a processualística europeia passou a se preocupar com a chamada efetividade do processo ou com o que se denominou "justo processo". A partir de então, verificou-se um verdadeiro fenômeno de "constitucionalização do Direito", especialmente do Direito Processual, cujos princípios ganharam assento constitucional, alterando a ótica do processo e voltando-se para uma visão baseada nos ideais de instrumentalidade e efetividade. O processo passou a ser visto a partir de seu resultado, não como um mero apêndice, mas resgatando a sua função de instrumento na concretização do direito material, buscando uma reaproximação entre ambos os ramos do Direito.

Desde então, acentuou-se não só a valorização do caráter publicístico do processo, como também o reconhecimento de uma ciência processual dominada pelo constitucionalismo (DINAMARCO, 1996, p. 65). Tais ideias se disseminaram por quase todo o planeta, influenciando fortemente a maioria das constituições após a Segunda Guerra Mundial, que erigiram, sistematicamente, princípios voltados à concretização do acesso à justiça e do devido processo legal como direitos fundamentais do cidadão.

No Estado Democrático de Direito Contemporâneo, o processo não pode resumir-se apenas a regular o acesso à justiça em sentido 
formal. Sua missão, na ordem dos direitos fundamentais, é proporcionar a todos uma tutela procedimental e substancialmente justa, adequada e efetiva. Daí falar-se, modernamente, em garantia de um "processo justo". (THEODORO JR. 2010, p. 221)

A Constituição brasileira de 1988 se preocupa em enunciar direitos e garantias fundamentais, entre os quais figuram os princípios básicos do "processo justo" - ínsitos no artigo $5^{\circ}$-, dentre outros, como o princípio da indeclinabilidade de jurisdição ou de pleno acesso à justiça (inc. XXXV); do juiz natural; do devido processo legal (inc. LIV); do contraditório e da ampla defesa (inc. LV); da vedação à utilização de provas ilícitas (inc. LVI); da publicidade dos atos processuais (inc. LX) e da exigência de fundamentação de todas as decisões judiciais (CF, art. 93, IX); da assistência jurídica integral e gratuita aos que comprovarem insuficiência de recursos (inc. LXXIV); e da duração razoável do processo (inc. LXXVIII).

O inciso LXXVIII, que trata da duração razoável do processo e da adoção de meios para assegurar a celeridade na tramitação dos processos judiciais e administrativos não fazia parte do rol primitivo do art. $5^{\circ}$ da Carta Magna. Entretanto, a ideia de duração razoável do processo já estava implícita na garantia do devido processo legal (THEODORO JR. 2010, p. 222).

Nos termos do $\S 2^{\circ}$ do art. $5^{\circ}$ da Constituição Federal, os direitos e garantias fundamentais não são apenas aqueles expressamente declarados em seu texto, mas incluem "outros decorrentes do regime e dos princípios por ela adotados, ou dos tratados internacionais em que a República Federativa do Brasil seja parte". Assim, não se poderia recusara direitos intimamente afetos à economia processual, independentemente de menção expressa, a categoria de direito fundamental na sistemática processual civil moderna (BEDAQUE, 2007, p. 171). Dessa forma, o direito à celeridade processual e, consequentemente, à duração razoável do processo seria uma garantia fundamental consagrada pela sistemática da Constituição de 1988.

Com a inserção do inciso LXXVIII ao artigo $5^{\circ}$ da Constituição, percebeu-se uma preocupação do legislador reformador em garantir 
expressamente a celeridade do processo, numa tentativa de dar início a uma reformulação do pensamento jurídico, mais voltado à superação de alguns dos mais perniciosos óbices que demonstra afetar a efetividade da prestação jurisdicional: a morosidade. Afinal, uma justiça tardia pode representar, muitas das vezes, uma verdadeira injustiça.

\section{0 tempo no processo}

O tempo é um agente contínuo. Ele não depende de qualquer atividade externa para o seu desenvolvimento e, por mais que a humanidade sonhe com essa possibilidade, não pode ser controlado, paralisado ou restituído. O tempo sempre ressalta mais o desgaste do que o êxito, uma vez que o êxito, depois de alcançado, com o curso do tempo, é ultrapassado e desgastado. É o tempo o curso inevitável para o desgaste, para o fim, para a morte.

Nas palavras de Dinamarco (2000, p. 98), "o valor que o tempo tem no processo é imenso e em grande parte reconhecido. Não seria imprudente comparar o tempo a um inimigo contra o qual o juiz luta sem trégua".

O processo não pode ser concebido como mero ordenamento de atividades, dotado de cunho exclusivamente técnico, integrado por regras externas e estabelecido pelo legislador de modo arbitrário, apesar do seu caráter formal. A própria estrutura que lhe é inerente depende dos valores adotados pela sociedade, não como mera adaptação técnica do instrumento processual a um objetivo determinado, mas como uma escolha de natureza política, ligada às formas e ao objetivo da própria administração judicial. O fim último do processo é dar razão a quem a tem, proporcionando um resultado justo e respeitando os caminhos e regras pré-estabelecidas pelo legislador, sem perder de vista o ideal da efetividade, que, muitas vezes, pode se perder com o passar do tempo.

Com o crescimento das sociedades e, por consequência, do número de conflitos levados ao Judiciário, o grande desafio da ciência jurídica atual é conciliar os institutos da segurança jurídica e a efetividade 
do processo, entendendo esta como uma garantia ao cidadão de uma tutela "que seja capaz de realizar, efetivamente, o direito afirmado pelo autor" (AMARAL, 2001, p. 7).

A relação jurídico-processual reclama, naturalmente, certo lapso temporal para que possa alcançar o seu desfecho. Independente de fatores ligados à morosidade e à burocracia, há uma relação intrínseca entre o processo e o tempo.

O processo se exterioriza por uma concatenação de atos processuais que necessitam da presença do tempo como fator que impulsiona a marcha processual. Ele requer, naturalmente, uma dilação temporal, na medida em que a solução dos conflitos de interesses e a pacificação social a que se destina não podem ser alcançadas instantaneamente, mas tão somente após a observância das formalidades legalmente preestabelecidas.

Segundo Lecionava Carnelutti (1971, pp. 176- 178),

El proceso dura; no se puede hacer todo de una vez. Es necesario tener paciencia. Se siembra, como hace el campesino, y hay que esperar pra recoger. Junto a la atención hay que colocar la paciencia entre las virtudes necesarias al juez y a las partes. Desgraciadamente éstas son impacientes por definición; impacientes como los enfermos, puesto que sufren también ellas. Uno de los cometidos de los defensores es el de inspirarles la paciencia. El slogan de la justicia rápida y segura, que se encuentra siempre en las bocas de los políticos inexpertos, contiene, desgraciadamente, una contradicción in adiecto; si la justicia es segura no es rápida, si es rápida no es segura. Algunas veces la semilla de la verdad pone años, incluso siglos, para convertirse en una espiga (veritas filia temporis).

O transcurso natural do processo atende aos postulados supremos do devido processo legal e da segurança jurídica, como valores inerentes ao Estado Democrático de Direito. E o tempo, consumido pelo processo, serve à preservação do due process of law, com a plena observância das 
garantias constitucionais, assegurando-se aos litigantes o contraditório e a ampla defesa com os recursos a ela inerentes.

A celeridade processual é de grande relevância para os litigantes, mas a segurança jurídica demanda que ela não prepondere em situações protegidas pela garantia constitucional da ampla defesa e do contraditório. Na apreciação do fator tempo pelo legislador, deve existir um exercício de ponderação de valores, respeitando-se o binômio tempo-segurança.

Tal como Janus, o Deus da "dupla face" da mitologia greco-romana, o tempo possui uma face que constitui verdadeiro óbice à célere solução dos litígios e outra que funciona como fator voltado à segurança dos litigantes, à medida que o transcorrer do iter procedimental, por meio da dilação probatória, do estudo da matéria litigiosa, do debate entre as partes e outros atos voltados à concretização do contraditório e da ampla defesa, serve ao magistrado como subsídio seguro para a formação de seu convencimento.

O que se apresenta nesse contexto é a necessidade de equilibrar tais garantias fundamentais, que podem parecer, a priori, inconciliáveis. Isso porque, por um lado, o processo deve observar fielmente as garantias constitucionais que asseguram aos litigantes o uso de todos os meios inerentes à defesa, os quais demandam certo lapso temporal; por outro, o processo deve observar, obrigatoriamente, uma razoável duração.

Assim, embora o tempo seja um fator crucial no processo, pode ele representar um verdadeiro inimigo invisível e implacável, contra o qual há que se lutar. O tempo desmedido corrói a percepção e o entendimento dos atos e fatos no processo, destrói o processo como um todo e, com ele, a possibilidade de uma resposta adequada, eficaz e eficiente.

$\mathrm{Na}$ atualidade, pensar que alguém teria o direito substancial, mas que este não lhe seria concedido em razão da demora na prestação da tutela jurisdicional já não mais satisfaz os escopos sociais do processo. O processo vale pelos resultados que produz na vida das pessoas, 
devendo assegurar à parte tudo aquilo a que se tem direito. (BRASIL JR., 2007, p. 31)

Daí a ideia de que o Direito Processual é o Direito Constitucional aplicado, significando, essencialmente, que o processo não se esgota dentro dos quadros de uma mera realização do direito material, pois se constitui em uma ferramenta de natureza pública indispensável para realização da justiça e da pacificação social (ALVARO DE OLIVEIRA, 2006, p. 12). Não só a comunidade jurídica, mas toda a sociedade clama por uma justiça que seja segura, mas também eficaz e rápida.

A exigência por celeridade é, portanto, o medo da aproximação da morte e do perigo de não fruição adequada do bem demandado judicialmente. Como não há como suprimir o tempo de qualquer fenômeno, menos ainda do processo, a prestação jurisdicional deve ser efetuada em tempo adequado, necessário e útil ao usufruto do bem a ser tutelado, obedecendo aos direitos fundamentais relativos ao processo, na certeza de que o tempo necessário e justo está inserido no direito ao devido processo legal.

\section{A introdução da duração razoável do processo como direito fundamental pela Emenda Constitucional $n^{\circ} 45$, de 2004}

Como já enunciado, consagrando o Estado Democrático de Direito e atendendo às exigências da sociedade contemporânea, o legislador constituinte de 1988 inseriu diversos princípios fundamentais do processo no Artigo $5^{\circ}$ da atual Constituição Federal, concedendo o status de direitos e garantias fundamentais a princípios basilares da processualística moderna. Todavia, desde a sua promulgação, a Constituição vem sofrendo inúmeras modificações, na constante busca por seu aperfeiçoamento, a fim de atender aos anseios sociais, políticos e econômicos. Por isso, foram editadas inúmeras Emendas à Constituição, sendo uma das mais relevantes a Emenda $n^{\circ}$ 45, de 2004, vulgarmente conhecida como "Reforma do Judiciário". 
A Emenda Constitucional $n^{\circ} 45$ foi editada sob a promessa de atender a um antigo apelo, principalmente da comunidade jurídica, lançando diretrizes e implementando mecanismos para solucionar os problemas da morosidade e da burocracia do Poder Judiciário, que a cada dia se mostrava mais incapaz de oferecer a prestação jurisdicional em um tempo razoável.

Acenando para um Judiciário mais ágil e eficaz, estabeleceu como direito fundamental a razoável duração dos processos e criou os Conselhos Nacionais de Justiça e do Ministério Público, responsáveis pelo controle da atuação administrativa, financeira e funcional dos órgãos encarregados da prestação jurisdicional.

Além disso, adotou uma série de providências destinadas a garantir a celeridade na tramitação dos processos, prevendo regras: a) para tornar ininterrupta a atividade jurisdicional, ao menos nas instâncias ordinárias; b) para garantir a proporcionalidade entre o número de juízes e a demanda judicial nas unidades jurisdicionais; c) determinar a imediata distribuição de processos em todos os graus de jurisdição; d) determinar a delegação da prática de atos de administração e de mero expediente a servidores do juízo; e) dispor sobre a proibição de promoção do magistrado que, injustificadamente, retiver autos em seu poder além do prazo legal, não podendo devolvê-los ao cartório sem o devido despacho ou decisão; f) estatuir súmula vinculante; e g) instituir a justiça itinerante e a descentralização da justiça, dentre outras medidas.

Atendendo aos anseios da sociedade por uma resposta estatal célere e eficiente por parte do Estado na solução dos conflitos, o legislador reformador tornou o princípio da razoável duração do processo direito público subjetivo constitucional e explícito, alocando-o no rol dos direitos e garantias fundamentais do Artigo $5^{\circ}$ da Constituição Federal de 1988.

Uma das projeções do due process of law, o princípio da razoável duração do processo esteve implícito em nosso ordenamento, embora de forma indireta e derivada; uma espécie de "norma sem disposição", que não está enunciada linguisticamente, mas decorre dos desdobramentos dos princípios do devido processo legal e do amplo acesso à justiça. 
Reconhecido na Convenção Europeia para Salvaguarda dos Direitos do Homem e das Liberdades Fundamentais, o princípio da duração razoável do processo se encontra insculpido em seu Art. $6^{\circ}$, in verbis:

Direito a um processo equitativo 1. Qualquer pessoa tem direito a que a sua causa seja examinada, equitativa e publicamente, num prazo razoável por um tribunal independente e imparcial, estabelecido pela lei, o qual decidirá, quer sobre a determinação dos seus direitos e obrigações de carácter civil, quer sobre o fundamento de qualquer acusação em matéria penal dirigida contra ela. O julgamento deve ser público, mas o acesso à sala de audiências pode ser proibido à imprensa ou ao público durante a totalidade ou parte do processo,quando a bem da moralidade, da ordem pública ou da segurança nacional numa sociedade democrática, quando os interesses de menores ou a proteção da vida privada das partes no processo o exigirem, ou, na medida julgada estritamente necessária pelo tribunal, quando, em circunstâncias especiais ,a publicidade pudesse ser prejudicial para os interesses da justiça. (grifo nosso)

A Convenção Americana de Direitos Humanos, também conhecida como Pacto de São José da Costa Rica, enuncia a garantia judicial de que:

Toda pessoa terá o direito de ser ouvida, com as devidas garantias e dentro de um prazo razoável, por um juiz ou Tribunal competente, independente e imparcial, estabelecido anteriormente por lei, na apuração de qualquer acusação penal formulada contra ela, ou na determinação de seus direitos e obrigações de caráter civil, trabalhista, fiscal ou de qualquer outra natureza. (grifo nosso)

Com a introdução explícita do direito à razoável duração do processo e aos meios que garantam a celeridade de sua tramitação, o Estado brasileiro assumiu definitivamente o compromisso de superar as omissões e deficiências no âmbito processual interno, tendo por escopo garantir a duração de todo e qualquer processo em um prazo razoável. 
A positividade jurídico-constitucional do direito à razoável duração do processo representa a vinculação não só do legislador infraconstitucional, de forma permanente, à sua realização, mas também dos poderes Executivo e Judiciário, servindo de limite material negativo ao Estado, devendo ser considerados inconstitucionais quaisquer atos atentatórios ao referido direito fundamental.

O ideal do processo justo e de resultados imprime a percepção de que a tutela jurisdicional deve ser não apenas disponibilizada ao cidadão, mas de que ela deve ser efetiva, célere e adequada, sendo considerada um direito fundamental que vincula não só o administrador, como também o legislador e o julgador, numa visão de que os direitos fundamentais possuem uma dimensão objetiva e, por isso, constituem um conjunto de valores objetivos e fins básicos do Estado.

O fato de tornar expresso o direito à celeridade processual demonstra, por parte do legislador, não só uma preocupação política, mas também social com os anseios de uma sociedade globalizada. Por outro lado, a mera previsão abstrata do direito à razoável duração do processo e a edição de leis infraconstitucionais que implementem tal objetivo não são suficientes para a sua efetivação, sendo necessário, além de medidas concretas tornando o exercício desse direito eficaz, um esforço político e econômico para uma real modernização não só dos equipamentos, mas da mentalidade do Poder Judiciário, permitindo que este invista em tecnologia, recursos materiais e recursos humanos em prol da uma justiça mais célere e eficiente.

Portanto, com base na Declaração Universal de 1948 e em tratados internacionais que tratem de garantias processuais, bem como em razão do conjunto de princípios e valores adotados pelo ordenamento brasileiro e a previsão expressa na Constituição Federal, o Estado brasileiro tem o dever de garantir, perante o poder público, o direito fundamental à celeridade processual a todos os litigantes, devendo ser coibido qualquer ato ou condutas violadora de tal direito, sob pena de responsabilização do Estado por prejuízos causados aos particulares. 


\section{A celeridade processual e a rápida solução dos litígios como fator de efetivação da tutela jurisdicional}

Conceituar celeridade processual não é tarefa facial, pois se trata de um conceito jurídico aberto; não há como estabelecer precisamente - alcance da expressão com antecedência, desvinculada das circunstâncias concretas. Não se pode precisar os atos ou fatos que são capazes de violar o direito à tutela jurisdicional rápida ou dentro de um prazo razoável. Utilizando um exemplo citado por Bedaque (2007, p. 67), o atraso de um dia é intolerável quando se trata de medida cautelar de separação de corpos, mas será mais do que razoável quando se tratar de condenação à restituição de indébito tributário, por exemplo.

O direito constitucional à razoável duração do processo e aos meios para garantir a celeridade vem contribuir como mais um meio para justificar a instrumentalidade substancial e o processo de resultados justos. Tais direitos podem ser invocados, por exemplo, para justificar a não aplicação de regras processuais inúteis, que somente atrasam o desenrolar do procedimento, sem necessidade ou razão que as justifique. A razoável duração do processo deve ser compreendida como o tolerável aguardo da solução definitiva das controvérsias, sem dilações indevidas, desnecessárias, inadequadas ou desproporcionais (BRASIL JR., 2007, p. 129).

A celeridade processual não se confunde com economia processual, pois não trata apenas da obtenção do provimento final com o menor esforço processual possível; está voltada ao destinatário da prestação jurisdicional. Como verdadeiro direito subjetivo, compreende uma duração adequada a uma justa solução do conflito de interesses, capaz de garantir a efetividade do provimento e a pacificação social.

A lentidão processual degenera o direito, corrói o resultado da prestação jurisdicional e faz como que o direito se perca no tempo da espera. Um tempo desnecessário e inútil é prejuízo. Suas consequências são vidas desperdiçadas, saúdes comprometidas, perdas e mais perdas em nome de uma regularidade ou justeza que se mostra injusta 
e desigual. A celeridade da prestação jurisdicional não se limita à tramitação do procedimento; refere-se à própria composição definitiva do conflito de interesses e a uma duração tolerável da discussão judicial de um direito substancial, que não pode se perder em razão de entraves formais.

Efetividade processual significa, antes de tudo, o perfeito alcance da finalidade do processo visto como instrumento ativo da distribuição da justiça e, mais do que isso, como forma de pacificação e modificação social, garantindo soluções ao mesmo tempo jurídicas e legítimas, o que pode se perder completamente no tempo.

O direito à celeridade processual e ao processo de resultados pode ser utilizado até como argumento para sustentar a possibilidade de o julgador ignorar regras procedimentais em nome do resultado justo na solução substancial das controvérsias (Meira Brasil Jr., 2007, pp. 13031). A título de exemplo, o mencionado autor descreve o caso de uma senhora que adquiriu um imóvel pagando parte do preço ao vendedor, sem que tivesse sido elaborada uma promessa de compra e venda. Posteriormente, descobriu-se que o imóvel havia sido vendido a terceiro de boa-fé, que registrou a escritura pública no respectivo cartório de imóveis. Sentindo-se lesada, ajuizou demanda formulando pedido expresso de anulação da escritura e de condenação do vendedor a outorgar-lhe a escritura pública, sem qualquer pedido eventual ou sucessivo.

Julgado improcedente o pedido, sob o fundamento de que a aquisição de propriedade imóvel somente ocorre com a transcrição do título aquisitivo no Registro Imobiliário, a apelação vai a julgamento trinta anos depois. Analisando o recurso, o tribunal reconheceu a existência do negócio jurídico de compra e venda entre a senhora e o terceiro de boafé. Entretanto, concluiu-se improcedente o pedido anulatório, bem como o de condenação do vendedor à outorga da escritura pública, tendo no máximo o direito da demandante ser indenizada pelo vendedor.

Como dizer a uma senhora de aproximadamente 70 anos (ao tempo do julgamento da apelação) que, além de não ter direito à casa 
que acreditara ter adquirido, no máximo ela poderia ser indenizada? E ainda, em razão da não existência de qualquer pedido alternativo ou sucessivo de perda e danos, ela somente poderia, após 30 anos de tramitação, ter direito a receber tal indenização por meio de ação própria, e que talvez demorasse mais 30 anos para ser resolvida?

A $2^{a}$ Câmara Cível do Tribunal de Justiça do Espírito Santo reconheceu a possibilidade de conversão da obrigação de fazer em perdas e danos, bem como a necessidade de respeito à razoável duração do processo, e condenou o demandado em perdas e danos, independente de qualquer pedido, tanto na inicial quanto no recurso de apelação. Nesse caso, o desrespeito à razoável duração do processo se mostrou tão grave a ponto de significar praticamente negação à tutela jurisdicional.

\section{A problemática da excessiva duração dos processos no Direito Comparado: a reforma processual civil italiana de 2009}

A lentidão na prestação jurisdicional constitui um dos mais antigos obstáculos da Administração da Justiça. A excessiva duração dos processos tem se caracterizado como um problema latente em muitos ordenamentos. Independentemente de a razão ao final ser atribuída ao autor ou ao réu, a demora na solução dos litígios acarreta angústia, desconforto e, muitas vezes, prejuízos de ordem material. Mesmo nos países de litigiosidade contida, por razões de ordem cultural ou social, não são raras as afirmativas de que ações devem ser empreendidas para tornar a tutela jurisdicional mais célere e efetiva, transformando o mote da duração do processo numa preocupação mundial.

Analisando a preocupação com a morosidade judicial no Direito Comparado, é interessante observar a forma como os ordenamentos jurídicos enfrentam o problema dos prazos processuais na atualidade. Na Itália, por exemplo, a excessiva duração dos processos cíveis tem sido preocupação latente - tanto da doutrina quanto da jurisprudência 
- desde o final do século XIX, entretanto, nem mesmo o movimento reformador que assolou o continente europeu após a Revolução Francesa foi capaz de imprimir celeridade nos provimentos jurisdicionais naquele país. Segundo pesquisa promovida pelo Banco Mundial, a Itália ocupa atualmente a $157^{\text {a }}$ colocação no ranking mundial em eficiência do sistema judiciário para solucionar controvérsias.

Com intuito de ter reconhecido seu direito à obtenção de um provimento jurisdicional dentro de um tempo razoável, cidadãos italianos chegaram a recorrer à Corte Europeia de Direitos do Homem, órgão do Conselho da Europa. A primeira sentença que reconheceu, por parte daquele país, a violação do direito a uma razoável duração do processo, datada de 25 de junho de 1987, no caso Capuano vs. Itália, condenou a Itália a pagar uma soma em dinheiro a título de indenização para uma jurisdicionada. A partir dessa decisão, milhares de outros cidadãos italianos começaram a demandar contra o seu país diante da Corte de Estrasburgo, chegando a provocar preocupação quanto ao seu funcionamento por parte do Conselho da Europa, em razão de seu abarrotamento por recursos italianos, que questionavam tanto a subsidiariedade da proteção prevista na Convenção quanto a existência de um remédio nacional interno que fosse eficaz (FALLETTI, 2006, p. 8).

As reiteradas condenações italianas na Corte Europeia de Direitos do Homem acabaram por desencadear mais uma reforma legislativa no país. Com isso, foi promulgada, em 24 de março de 2001, a lei nº 89, conhecida como Lei Pinto, que introduziu medidas de aceleração e reparação contra o desrespeito à razoável duração dos processos. O referido diploma legal criou um remédio nacional de reparação, que reconhece no exercício da jurisdição interna a violação à razoável duração do processo. Entretanto, ele não propicia as condições efetivas a fim de que o processo possa resolver-se em um tempo razoável.

Dessa forma, embora a Itália esteja empenhada em criar mecanismos voltados à solução da lentidão processual, que aflige não só a comunidade jurídica, mas principalmente o cidadão, degenerando os efeitos do provimento jurisdicional e comprometendo a justiça do caso 
concreto, a questão ainda está longe de ser totalmente solucionada. O problema da excessiva duração dos processos desencadeou uma série de reformas legislativas, que se intensificaram principalmente nas últimas décadas, culminando com a mais expressiva, ocorrida em 2009.

Com o objetivo de introduzir disposições para o desenvolvimento econômico, a simplificação e a competitividade em matéria de processo civil, na tentativa de acelerar a tramitação dos processos e contribuir para a eliminação de cerca de 5 milhões de procedimentos pendentes no Judiciário italiano, em 19 de junho de 2009, foi publicada na Itália a Lei de $n^{\circ} 69$, que modificou todo o código de rito italiano e, em alguns aspectos, apresentou uma verdadeira ruptura com o processo civil tradicional.

Modificando sensivelmente o processo civil no que diz respeito à duração, podemos destacar, dentre as principais alterações trazidas pela reforma de 2009: 1) a alteração das normas subjacentes de regulamentação de despesas da lide e aumento dos poderes sancionatórios do juiz; 2) a introdução de uma medida de coerção indireta, as conhecidas astreintes francesas, prevendo um reforço na condenação judicial nas obrigações de fazer infungíveis ou de não fazer; 3) a introdução da mediação civil, visando uma conciliação extrajudicial entre as partes; 4) a criação do procedimento sumário de conhecimento, mais simples e alternativo ao rito ordinário; 5) a simplificação dos ritos através da redução de todos os procedimentos em três modelos processuais previstos no Código de Processo Civil (rito ordinário de conhecimento, rito do trabalho e rito sumário de conhecimento); 6) a revogação do rito societário e a aplicação do rito ordinário para as causas relativas a acidentes de trânsito; 7) a inserção de sanções processuais à parte que retarda, com o seu comportamento, a conclusão do processo; 8) a modificação do regime de distribuição de competência e de sua decisão; 9) a ampliação da competência do juiz de paz em razão do valor da causa; 10) a redução dos prazos de suspensão do processo, bem como a modificação dos prazos processuais; 11) a introdução da prova de "testemunha escrita", com prévio acordo entre as partes; 12) o estabelecimento do efeito retroativo da correção de 
vícios de representação ou assistência; 13) a aceleração da realização de perícia técnica; 14) o estabelecimento de novos critérios de redação e publicação das sentenças; e 15) a introdução de um "filtro", como novo requisito de admissibilidade para o recurso de cassação, com a finalidade de desafogar a Corte de Cassação e reduzir o número de recursos que chegam à apreciação, que é um dos pontos mais polêmicos dessa reforma.

A reforma processual civil italiana de 2009 previu a obrigatoriedade do governo de, no prazo de 24 meses, emitir decretos para simplificar os procedimentos civis de conhecimento, regulados por legislação especial, reinserindo-os na jurisdição ordinária. O seu objetivo precípuo foi promover a simplificação da forma procedimental e, finalmente, vencer o obstáculo da excessiva duração dos processos cíveis, completando mais um episódio na longa jornada de tentativas reformistas, iniciada no século passado. No país dos grandes processualistas do século XIX, a morosidade na prestação da justiça constitui um obstáculo a ser superado.

\section{O compromisso com a rápida solução dos litígios e a enunciação da celeridade processual no capítulo I do novo Código de Processo Civil}

Com a constitucionalização expressa do princípio da razoável duração do processo, o legislador brasileiro acabou por consolidar definitivamente $\mathrm{o}$ direito à celeridade processual como direito fundamental. Este requer, para a sua concretização, a realização de políticas públicas direcionadas à dignidade do indivíduo, bem como ações que objetivem garantir e promover efetivamente tal direito, sob pena de, ao final, desempenhar papel meramente programático, com vigência apenas formal, sem qualquer possibilidade de concretização e eficácia material.

O atual Código de Processo Civil brasileiro passou por inúmeras modificações em seu texto original, introduzidas por mais de sessenta 
diplomas legais. Entretanto, as transformações na estrutura do Poder Judiciário, impulsionadas pela mudança do perfil da sociedade brasileira e o crescimento - não só quantitativo, mas qualitativo - das demandas nas últimas décadas, provocaram um enfraquecimento da coesão entre as normas processuais, o que levou a comunidade jurídica a defender a necessidade de uma completa reforma das regras que regem o processo civil.

A mensagem constante no anteprojeto do novo Código de Processo Civil enunciou que "chegara o momento de reformas mais profundas no processo judiciário, há muito reclamadas pela sociedade e especialmente pelos agentes do Direito, magistrados e advogados". Elaborado por uma comissão de juristas, sob a presidência do ministro do Superior Tribunal de Justiça, Luis Fux, o anteprojeto de novo código de rito teve como ideologia norteadora dos trabalhadores conferir maior celeridade à prestação da justiça, no afã de cumprir a promessa constitucional da "duração razoável dos processos" (FUX, 2011, p. 1).

O projeto do novo diploma processual civil passou por várias discussões através de audiências públicas, recebendo um grande número de propostas de emendas. Atualmente, está materializado no Projeto de Lei no 166/2009, que já teve sua votação finalizada pelo Senado e se encontra em tramitação na Câmara Federal. É importante ter em mente que o Código de Processo Civil não pode ser entendido simplesmente como um ajuntamento de regras meramente técnicas e de interesse exclusivo do operador do Direito. Tal Digesto regula não só os procedimentos judiciais e atos internos do Judiciário, mas também a forma com que deve ser prestada a tutela jurisdicional, os deveres, direitos e garantias dos magistrados, auxiliares da justiça e das partes e seus procuradores, o que é de interesse de toda a sociedade.

E mais, atualmente, quando se fala em reforma legislativa, necessariamente, a primeira ideia que nos vem à mente é de que ela deve ter como escopo adaptar-se às novas realidades e práticas, tendo como foco os princípios constitucionais delineados pela Constituição de 1988. Não podia ser diferente com o Processo Civil. Assim, o projeto 
de novo código de rito enuncia em seu artigo 10: "o processo civil será ordenado, disciplinado e interpretado conforme os valores e os princípios fundamentais estabelecidos na Constituição da República Federativa do Brasil, [...]."

Nos primeiros artigos do capítulo I do novo Código, intitulado "Dos Princípios e das Garantias Fundamentais do Processo Civil", fica evidenciada a filosofia que guiará as novas regras por ele introduzidas. Em seu artigo $4^{\circ}$, dispõe que "as partes têm direito de obter em prazo razoável a solução integral da lide, incluída a atividade satisfativa". Admitindo a premissa de que o processo é um encadear sucessivo de atos destinados a servir de instrumento pelo qual o Estado aplica o direito material abstrato no caso concreto, conferindo jurisdição e legitimidade às soluções dos conflitos, isso deve ocorrer da maneira mais célere possível.

Inserindo-se no novo modelo de "processo justo", a sistemática processual deve ter por essência e finalidade dar razão a quem tem razão e proporcionar a pacificação social, instrumentalizando um resultado justo e eficaz, esculpido com base no ideal de que o processo deve ser informado pelos preceitos da dignidade da pessoa humana.

Há muito se verificou, tanto na doutrina jurídica como em outros ramos das Ciências Sociais, o pensamento de que o Judiciário brasileiro é moroso, sobretudo em razão de uma legislação atrasada e de sua estrutura formalista e burocratizada, identificando-se tal aspecto como a grande mazela que enfraquece a efetiva tutela de direitos aos juridisdionados, os quais acabam por identificar uma imediata correlação entre isso e a ineficiência estatal, gerando o consequente descrédito na justiça brasileira.

Cabe relembrar que a demora na prestação jurisdicional gera a sensação de ser nociva, de submeter os sujeitos do processo a desconfortos, angústias,e até mesmo lesões de ordem material; por outro lado, o transcurso de certo lapso temporal é essencial à prestação jurisdicional, que necessita de um tempo mínimo a fim de garantir que os mecanismos de processamento dos feitos sejam realizados. 
Deve, pois, todo e qualquer processo respeitar os postulados do devido processo legal, da ampla defesa e do contraditório, além das demais garantias fundamentais inerentes à pessoa humana, dentre os quais, a igualdade, a publicidade dos atos judiciais, e, ainda, perseguir a efetivação de uma duração do processo que seja razoável. Tais elementos devem ser rigorosamente resguardados quando da busca do jurisdicionado pela tutela dos direitos, a ser prestada por meio de uma jurisdição adequada.

O legislador deixou claro que a razoável duração do processo deve ser considerada na totalidade da prestação do serviço jurisdicional, desde seu início até a sua satisfação. Há, portanto, que se considerar o tempo razoável de tramitação do processo para além do provimento final pelo órgão jurisdicional, levando em conta a efetiva satisfação do direito tutelado no mundo dos fatos. Razoável deverá ser o tempo necessário para a cognição da causa, todo o seu processamento e a efetiva entrega do bem pretendido pela parte, ou seja, de todo o iter processual até a efetivação do provimento final.

Assim, para consecução dessa duração razoável, a necessária celeridade do processo, caracterizada pela universalidade e irrenunciabilidade, serve como fator de limitação da atividade jurisdicional. Seu conteúdo deve ser harmonizado com o conceito de acesso à justiça, no intento da efetividade, ao se concentrarem seja na busca de formas diferenciadas de tutela de direitos, seja por meios alternativos de solução de conflitos, seja pela participação democrática do cidadão na persecução da solução do litígio submetido ao judiciário.

Em seguida, os artigos $5^{\circ}$ e $8^{\circ}$ tratam do direito de participação efetiva das partes no processo. Imprimindo sentido de uma participação/ colaboração, o código exige das partes cooperação mútua e com o julgador para a rápida solução da lide, à medida que devem fornecer subsídios ao juiz para que ele profira decisões, realize atos executivos e determine a prática de medidas urgentes, devendo ainda colaborar com a identificação das questões de fato e de direito e abster-se de provocar incidentes desnecessários e procrastinatórios. 
Admitindo a forte influência da atividade das partes no provimento final, além de enunciar a garantia de participação ativa das partes no processo, o legislador se preocupa em exigir que esta seja colaborativa, não podendo criar obstáculos a quaisquer atos dos quais possa se valer o julgador para chegar ao fim da marcha processual.

Mais adiante, o legislador também procura deixar claro seu compromisso com o processo de resultados, justo e équo, bem como com a celeridade processual, proclamando em seu artigo 60: "ao aplicar a lei, o juiz atenderá aos fins sociais a que ela se dirige e às exigências do bem comum, observando sempre os princípios da dignidade da pessoa humana, da razoabilidade, da legalidade, da impessoalidade, da moralidade, da publicidade e da eficiência."

Ao enunciar a necessidade de observação da eficiência na aplicação da lei processual, o legislador demonstra a preocupação com a efetividade da prestação jurisdicional, refletindo, mais uma vez, ideais de justiça e princípios fundamentais, tendo como finalidade o acesso a uma ordem jurídica que seja justa e célere na solução dos litígios a ela submetidos, ao fundamento de que somente procedimentos ágeis e eficazes realizam a verdadeira finalidade do processo (TEIXEIRA, 1996, p. 887).

Disso, temos que o projeto de novo Código de Processo Civil deixa claro, em seus primeiros dispositivos, o compromisso com a efetivação dos direitos fundamentais e a sua busca pela compatibilização do processo e da atividade jurisdicional com os princípios constitucionais, a partir de um processo justo, eficiente e capaz de garantir a efetiva pacificação social.

No decorrer de seus artigos, a nova legislação processual trata de regular uma série de outros mecanismos voltados à concretização do direito à celeridade processual enunciado em seu primeiro capítulo. Dentre eles, podemos citar: a possibilidade de concessão de tutela de urgência e de tutela à evidência; o incidente de resolução de demandas repetitivas; a possibilidade de o réu formular pedido independentemente do expediente formal da reconvenção, que desapareceu; a possibilidade 
de alegação de vários incidentes processuais em preliminar de contestação, em razão da extinção de vários daqueles; novas formas de intervenção de terceiros, pois, em razão da extinção de algumas e fusão de outras, criou-se um só instituto que abrange as hipóteses de denunciação da lide e de chamamento ao processo; a possibilidade de deferimento de medida acautelatória mediante demonstração pela parte do fumus boni iuris e do perigo de ineficácia da prestação jurisdicional, em função da extinção das ações cautelares nominadas; dentre outros.

Desse modo, pode-se inferir que o projeto de novo código de rito é essencialmente instrumentalista, imprimindo uma perspectiva constitucional, contribuindo para afastar o processo das construções conceituais e meramente técnicas e inseri-lo na realidade política e social, comprometendo-se em acelerá-lo ao máximo, desde que a nova velocidade imposta não gere prejuízo às partes, não cause surpresas e não inviabilize o exercício de direitos legítimos.

Afirmam Marinoni e Mitidiero (2010, p. 60):

Se é para pensar em nova codificação para o processo civil, é imprescindível que o Código apareça marcando pela nossa cultura - que é a cultura do Estado Constitucional - e possa servir à prática sem descurar das imposições que são próprias da ciência jurídica, como necessidade de ordem e unicidade, sem as quais não há como falar em sistema nem tampouco cogitar de coerência que lhe é essencial. Isto quer dizer que o Código deve ser pensado a partir de eixos temáticos fundados em sólidas bases teóricas. (...) Isto de modo nenhum quer dizer, todavia, que um Código de Processo Civil não deve servir à prática ou, muito menos, que não deve se preocupar com problemas concretos. É claro que não. Um Código de Processo Civil tem antes de qualquer coisa um compromisso inafastável com o foro. Deve servi-lo. Este compromisso, contudo, deve ser entendido e adimplido dentro de um quadro teórico coerente. A recíproca implicação entre teorias e prática deve ser constante a fim de que a legislação processual civil possa constituir meio efetivamente idôneo para resolver problemas concretos, cumprindo com o seu desiderato de outorgar adequada proteção ao direito fundamental ao devido processo legal. 
A partir das críticas e divergências apontadas no PL 8046/2010 pelos especialistas de todo o país, que participaram das audiências públicas realizadas pela Comissão Especial, o Deputado Miro Teixeira (PDT/RJ) apresentou o Projeto de Lei n² 2963/11 para alterar diversos dispositivos do Código de Processo Civil. A estrutura desse projeto é diversa daquele aprovado no Senado, modificando o Código de 1973; diferentemente da iniciativa do Senado (PL 8046/2010, ou PLS 166/2010 na origem), que optou por um novo Código de Processo Civil. O grupo de juristas convidados por Miro Teixeira aproveitou para a construção do PL 2963/11 o texto do Código de 1973, porém, acrescentou temas, ainda não tratados, que há muito repercutem na comunidade jurídica, como: o incidente de resolução de demandas repetitivas (Art. 495-A. a 495-S) e o incidente de desconsideração da personalidade jurídica (art. 45-C a 45-E).

Também integram a proposta do PL 2963/11: procedimento novo denominado "dissolução parcial da sociedade" (art. 585 a 595); dispositivo que transfere às câmaras de conciliação e mediação privadas credenciadas junto ao Poder Judiciário, conforme regras a serem estabelecidas pelo Conselho Nacional de Justiça, toda a atividade conciliatória (art. 153-A); manutenção do instituto da reconvenção e a redução da figura da exceção aos casos de impedimento ou suspensão, com o que se preservam as três respostas típicas do processo civil previstas pelo conhecido art. 297 - contestação, exceção e reconvenção (art. 299); a ampliação das hipóteses numerus clausus de admissibilidade do agravo de instrumento para, fundamentalmente, permitir o recurso contra decisões que indefiram provas, invertam o ônus da prova ou admitam prova ilícita ou emprestadas; e manutenção do recurso do agravo retido (Art. 522, parágrafo único). Já no que concerne ao processo cautelar, adotou-se a medida da introdução do instituto da estabilização dos efeitos (art. $271, \S \S 10^{\circ}, 11^{\circ}$ e $12^{\circ}$ ).

Outras dezenas de dispositivos do Código de 1973 foram modificadas em suas redações - muitos divididos, outros revogados. Títulos, seções e subseções novos também foram criados, de modo a atualizar o diploma processual vigente. 
O PL 2963/11 foi recentemente apresentado e ainda aguarda despacho. Existe a possibilidade, prevista regimentalmente, de o projeto do deputado Miro Teixeira ser apensado ao PL 8046/10, por tratarem de assunto correlato. Caso tal perspectiva se concretize, o parlamentar poderá atuar para garantir que sua proposta componha um substitutivo ao PL 8046/2010, a ser apresentado pelo relator geral do projeto, Deputado Sérgio Barradas Carneiro (PT/BA). Ademais, já se fala em um substitutivo que condensará as propostas de ambas as casas, a fim de propiciar a aprovação.

\section{Conclusão}

A morosidade do processo é fator de degeneração da tutela de direitos, desqualifica os resultados do processo e faz como que todo o esforço que o Estado tenha dirigido à pacificação do conflito se perca e evapore no tempo da espera. Um tempo inútil e desnecessário desperdiça vidas, compromete a saúde e a segurança do cidadão, gera descrédito para o Estado e causa injustiças. A tutela efetiva de direitos através do processo significa, antes de tudo, o alcance pelo próprio procedimento de sua real finalidade como instrumento ativo garantidor da distribuição da justiça e concretização da pacificação social. A efetividade dos direitos está diretamente relacionada à garantia de soluções jurídicas e legítimas, o que pode se perder completamente no tempo.

Em Direito Processual, mais do que em outros ramos do Direito, na condição de trabalho de aplicação da regra geral ao caso concreto, realizando uma verdadeira instrumentalização da tutela de direitos, o compromisso com a celeridade se relaciona com os fins do Direito e da própria tarefa afeita ao Poder Judiciário.

Aexigência da celeridade está intimamente relacionada com o medo dos efeitos danosos que o tempo pode imprimir à tutela jurisdicional. Ante a impossibilidade de supressão do fator tempo de qualquer fenômeno, especialmente do processo, a prestação jurisdicional deve observar um tempo que seja adequado, necessário e útil ao usufruto do bem a ser 
tutelado, observando todos os direitos fundamentais, na certeza de que esse tempo deve estar inserido no direito ao devido processo legal.

A excessiva duração dos processos tem se caracterizado como um problema nos ordenamentos modernos. Diversos países, a exemplo do Brasil e da Itália, têm realizado importantes reformas em matéria processual civil como forma de imprimir maior brevidade aos litígios, transformando a morosidade processual numa preocupação mundial.

Ante o exposto, fica evidenciado o compromisso que o projeto de novo Código de Processo Civil assume com a rápida solução dos litígios, com vistas a garantir o direito fundamental à celeridade processual, não só impulsionado pela expressa enunciação deste no texto constitucional, mas também em função da nova ótica do processo civil, entendido como verdadeira ferramenta de natureza pública, indispensável para a realização da justiça e da pacificação social.

Assim, embora o direito à celeridade processual seja de extrema importância para a real efetivação dos direitos, não se pode esquecer que o valor celeridade colide diretamente com a segurança jurídica, devendo, pois, haver uma ponderação para que um não exclua completamente o outro. Tão importante quanto a celeridade é a segurança jurídica, a proteção das garantias constitucionais dos litigantes, como o contraditório e o devido processo legal. Não se pode, somente para se obter uma razoável duração do processo, ignorar as garantias constitucionais que visam assegurar um processo justo e équo na solução das controvérsias. Porém, isso não quer dizer que a razoável duração do processo é um princípio cuja aplicação não terá utilidade para a ciência processual. Pelo contrário. O princípio irá justificar um processo de resultados mais justos à medida que tem como efeito minimizar os danos causados pelo tempo, autorizando uma instrumentalidade substancial na composição da lide. 


\section{Referências}

AMARAL, Júlio Ricardo de Paula. Tutela antecipatória. São Paulo: Saraiva, 2001.

BEDAQUE, José Roberto dos Santos. Efetividade do processo e técnica processual. 2. ed. São Paulo: Malheiros, 2007.

BRASIL JÚNIOR, Samuel Meira. Justiça, direito e processo. São Paulo: Atlas, 2007.

CARNELUTTI, Francesco. Derecho procesal civil y penal. Buenos Aires: Ediciones Jurídicas, 1971.

CINTRA, Antônio Carlos de Araújo; GRINOVER, Ada Pellegrini; DINAMARCO, Cândido Rangel. Teoria geral do processo. 19. ed. São Paulo: Malheiros, 2003.

DINAMARCO, Cândido Rangel. Fundamentos do processo civil moderno. São Paulo: Revista dos Tribunais, 2000. v. I.

Malheiros, 1996.

A instrumentalidade do processo. 5. ed. São Paulo:

FALLETTI, Elena. II dibattito sulla ragionevole durata del processo tra la corte europa dei diritti dell'uomo e lo stato italiano. Revista da Ajuris, Porto Alegre, n. 101, p. 335-370, 2006.

FUX, Luiz. O novo processo civil brasileiro (direito em expectativa): reflexões acerca do projeto do novo código de processo civil. Rio de Janeiro: Forense, 2011.

MARINONI, Luiz Guilherme; MITIDIERO, Daniel. O projeto do CPC: críticas e propostas. São Paulo: Revista dos Tribunais, 2010.

OLIVEIRA, Carlos Alberto Alvaro de. O formalismo-valorativo no confronto com o formalismo excessivo. Revista de Processo, São Paulo, n. 137, p. 7-31, 2006.

TEIXEIRA, Sálvio de Figueiredo. A reforma processual na perspectiva de uma nova justiça. In: TEIXEIRA, Sálvio de Figueiredo (Coord.). 
Reforma do código de processo civil. São Paulo: Saraiva, 1996. p. 885-906.

THEODORO JÚNIOR, Humberto. Processo cautelar. 22. ed. São Paulo: Universitária de Direito, 2005.

Recebido em: 27/02/12

Aprovado em: 14/02/13 